\title{
ORGANIZATIONAL, PSYCHOLOGICALAND PEDAGOGICAL CONDITIONS FOR THE USE OF E-BOOKS AND E-TEXTBOOKS AT SCHOOL
}

\author{
Dr. Iryna VOROTNYKOVA \\ ORCID: 0000-0003-1211-8885 \\ Department of Natural Sciences and Mathematics \\ Education, Institute of In-Service Teachers' Training of Borys Grinchenko Kyiv University \\ Kyiv, Ukraine
}

Received: 02/07/2018 Accepted: 21/01/2019

\begin{abstract}
The article defines the organizational, psychological and pedagogical conditions for the use of e-books and e-textbooks at school. The difference between e-books and e-textbooks is distinguished on the basis of systematization and comparison of scientific positions. Content analysis is made to determine the organizational and pedagogical conditions for the introduction of e-textbooks. The experience of using e-textbooks and e-books at school was generalized based on the results of a regional experiment, in which 25 schools participated. The results of the survey and questioning of 352 students, 296 teachers, and 357 parents are described. The results reveal the needs of respondents in e-textbooks and e-books, identify the advantages and disadvantages of their implementation. The main organizational, psychological and pedagogical conditions are defined. These are educational policy concerning the introduction of eLearning (requirements for mandatory e-textbooks, financial support for purchasing and updating, examination, standards for e-textbooks), availability and diversity of e-textbooks and e-books on the market of educational services, logistic, educational and methodological support of educational institutions, ergonomics, readiness of teachers, students, their parents to use e-textbooks and e-books, digital competence of teachers and students.
\end{abstract}

Keywords: e-Book, e-textbook, e-learning, interactive e-tutorials, digital textbooks.

\section{INTRODUCTION}

Globalization, the development of the information society and knowledge society promote SMARTEducation and require a change in the content of education, the development of new techniques for the creation and use of eLearning content, that is rapidly evolving and becoming more diverse in the form of presentation. There are fundamental changes in pedagogy. Education is becoming personal, networked and adapted, using accessible and open content (Keats \& Schmidt, 2007).

Distribution of smart systems, virtual and complementary reality, mobile devices also leads to the need for content modification, the introduction of microlearning, U-learning, e-Learning, which will allow students to study during the whole life from any device and be constantly in the information and education environment. The challenge for the school is to prepare students to take responsibility for their lifelong learning with the use of digital resources and tools. The rapid development of mobile devices facilitates the rapid dissemination of e-textbooks that can be used in real time and for distance learning (Fojtik, 2015). The development of cloud services and Web 2.0 services provides new opportunities for the use and creation of e-textbooks and the introduction of open education (Lee, Messom \& Kok-Lim, 2013). Incorporation of digital technologies into the innovation and transformation processes of the society, the development and management of the learning environment are extremely important tasks due to which students can attend virtual classes, museums, use e-textbooks and other online tutorials from many sources at any time of the day or night (Goodyear \& Retalis, 2010). E-books or e-textbooks offer universities or schools the additional environment, instructions or recommendations that improve the quality of learning. According 
to the scientists from Malaysia, there are significant benefits of using e-books as textbooks in schools, and this is a new paradigm, especially for developing countries. E-books are different in terms of content and design, but all of them should meet the needs, abilities, interests of students and take into account the level of their knowledge. (Embong et al., 2012).

In order to provide inclusive education, it is necessary to use e-textbooks that take into considertion the peculiarities of teaching students with special needs, for instance, visually impaired ones. An e-textbook that contains two subsystems: Writer (comprising various categories of interactive exercises) and Reader (providing multimodal interaction, having search functions, marking, suggestion repetition, comments from users, activity record, and context-sensitive help for the dual user interface) can be an example. (Grammenos et al., 2007).

The content of e-books and e-textbooks for higher school should contain more research evidence. That was confirmed by a study at one of the UK universities (Rowlands, Nicholas Jamali, Huntington, 2007). The survey identified the needs of students in various types of e-books: textbooks (59.9\%), reference books (52.4\%), research monographs $(46 \%)$.

The findings of the researchers gave answers to the questions about the conditions for the transition to e-textbooks and the choice of technologies for its implementation. They defined the conditions for the introduction of e-textbooks. Among them there is ensuring low cost of educational materials, standardization of content and its updating, improvement of e-content perception, reduction of health risk, protection of copyright. Technologies for creating and using e-textbooks can be divided into Hardware Technology (Multitouch Technology, Electronic Paper, Flexible Display) and Software Technology (Reader Applications, Web 2.0 in Education, Web Services, Cloud Computing, Visual-Syntactic Text Formatting) (Lee, Messom \& Kok-Lim, 2013).

A promising direction for the development of e-textbooks is the study of hibrid e-textbooks, which allow you to combine educational content with smart devices in the classroom, using both digital publications and the Semantic Web tools (Ghaem Sigarchian and all, 2018).

Teachers pointed out that the design of interactive e-books helps students develop the necessary learning skills: technological abilities, reading and writing skills, the ability to cognize and meta-knowledge. In addition, students note that interactive e-books positively influence their evaluation through the use of audio and visual content (Batoon, Glasserman MORALES, \& Figueroa, 2018).

\section{Problem of Research}

The development of ICT and e-resources contributes to the introduction of digital resources in education and promotes scientific research on the conditions and consequences of the use of e-books, e-textbooks at school. The development of the e-textbooks industry has been widely reflected in the scientific researches on the effectiveness of their use, but the definition of organizational, psychological and pedagogical conditions for the use of e-textbooks and e-books at school remain beyond the attention of researchers. The views of teachers, students and their parents on the feasibility of using e-textbooks and e-books from a certain age and their impact on the success and health of children still require being studied. An additional analysis of the use of the concepts of "digital textbook", "e-textbook", "e-book" needs to be made to determine the opportunities, advantages and disadvantages of using these tools at school.

\section{Research Focus}

To determine the conditions for the introduction of e-textbooks and e-books at school, we first determine their differences and the possibilities of use. The analysis of search queries in Google's trends has shown that in different parts of the world there are different approaches to the use of terms e-book, digital book, e-textbook. The most commonly used concept in science and in life is the term e-book. 


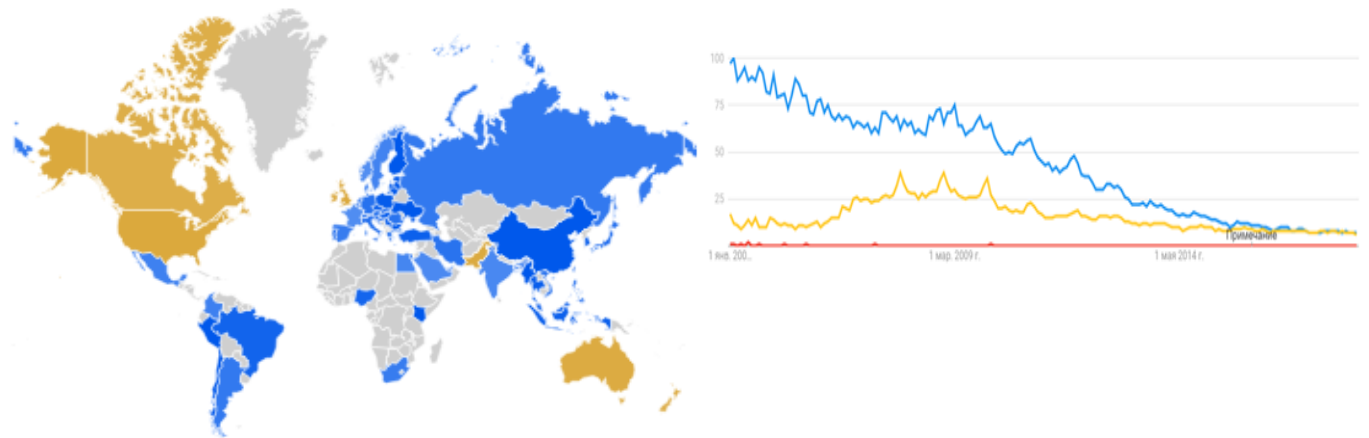

Figure 1. The analysis of search queries for using the terms e-book, e-textbook, digital book in Google's trends

The evolution of electronic materials from the earliest implementations at the beginning of the age of the Internet until today determines that most e-books are the original versions of classical (printed) analogues. This does not provide them with a particular advantage in using information technology. The first e-books were created by the volunteers manually, and the development of ICT and digitization or scanning allowed to create and maintain the work of well-known digital libraries and encyclopedias (https://www.wdl.org, https://books.google.com, www.theeuropeanlibrary.org).

The conceptual foundations for the formation of the world's digital funds are the digitization of archival and library funds from different countries (Library and Archives Canada, National Library of Australia, Bibliothèque nationale de France, British Library, Vernadsky National Library of Ukraine). When creating digital libraries, it is important to identify technical and technological standards based on an internationally accepted system of requirements that will integrate digital resources into global digital projects.

C. Armstrong analyzes the concept of a book and e-book in science and proposes to define e-books as 'any content that is recognizably 'book-like', regardless of size, origin or composition, but excluding serial publications, made available electronically for reference or reading on any device (handheld or desk-bound) that includes a screen (Armstrong, 2008).

E. Morgan wrote in the 20th century, 'Electronic books are not just e-texts. E-books mean a combination of hardware/software used to read electronic data on a portable electronic device specially designed for such purposes' (Morgan, 1999).

E-books can be defined as books that are ready to be read by computers or e-book readers, and they have some other additional features than printed books: visual and sound effects, and interactive links. The technology of e-books is supported by hardware, software and standard protocols, and some of its advantages and disadvantages have become an integral part of our academic and everyday life (Anameric \& Rukanc1, 2003).

The use of digital tools requires new ways of thinking and teaching, advanced training programmes. Something more than digital tools is needed to implement e-textbooks (Gronlund, Wiklund \& Boo, 2018). A professional development course has shown that e-textbooks allow a teacher to use digital instruments and new approaches and prompt creative reasoning and argumentation processes (Swidan, \& Abu-Abdoon, 2018).

An e-textbook is a digitized (or electronic) form of a textbook that usually requires approval by the government when it is used in the K-12 education system (Lee, Messom \& Kok-Lim, 2013). Therefore, an e-textbook can be an e-book or a scanned version of a printed textbook.

E-textbooks differ from e-books in having both interactive links and interactive elements which are created using Adobe Flash or Java technology and appropriate for use on different devices (Pesek, Zmazek, \& Mohorcic, 2014).

Digital textbooks should provide educational content through multimedia tools such as video, animation and virtual reality and their interactive features should stimulate individualised learning (Jang, 2014). 
Researchers believe that it is the format of digital resources that is the basis for the classification and understanding of the difference between the concepts of e-books and e-textbooks. E-textbooks can be classified according to their content (Pesek, Zmazek \& Mohorcic, 2014): d-textbooks (digitized e-textbook). They fully repeat the text formats of textbooks (pdf, EPUB2); r-textbooks (rich textbooks). Video, sound and the basic questions for self-control are added to d-textbooks. I-textbooks (interactive e-textbooks): interactive elements (simulators, didactic games, interactive models, maps, analytics, etc.) in HTML 5 and EPUB 3 format are added to r-textbooks.

Some e-textbooks have advantages over classical textbooks and they are called i-textbooks (interactive textbooks). This term identifies the new generation of e-textbooks that use the new media and provide good interaction with the user. The interactive elements of $\mathrm{i}$-textbooks contribute to self-study and allow students to perform their activities many times on different sets of input data. The main technological advantage of i-textbooks is that they work on all devices because their content is developed using script-supported HTML5 tools JavaScript (Pesek, Zmazek \& Mohorcic, 2014).

The desirable characteristics of a good e-textbook are the following (Lokar, 2015): availability on the Internet with the possibility to transfer to your own funds); adaptation to the needs of teachers, students and their groups; cost efficiency and productivity by reducing the time and money spent on creating and future changes and adaptations; adaptability to technology changes without redevelopment and transcoding costs; the ability to use different tools in different learning environments; the use of parts of the e-textbook in different contexts. The focus of our study is to summarize the best practice of using different types of e-textbooks and e-books and to determine which organizational, psychological and pedagogical conditions for using digital textbooks are effective.

\section{PURPOSE OF THE STUDY}

The purpose of the study is to define organizational, psychological and pedagogical conditions for the use of e-books and e-textbooks at school. The objectives of the study are to define organizational, psychological and pedagogical conditions for the use of e-books and e-textbooks, to analyses surveys on training with digital textbooks in order to determine the opportunities, disadvantages and benefits of their use at school.

\section{METHOD}

The research was carried out within the framework of the regional experiment of the research work "Organizational, psychological and pedagogical conditions for the introduction of elements of eLearning at school". The students of 5th, 6th grades from 25 schools in the city of Kiev took part in the research. They received netbooks at regional funds and trained with e-books and e-textbooks.

The methods of research are theoretical: systematization and comparison of scientific regulations, experience of introduction of e-books and e-textbooks at school to determine the possibilities of their use; empirical: observation, questionnaires for determining the needs of teachers, students and their parents; content analysis to determine the organizational and pedagogical conditions for the introduction of e-textbooks. The purpose of the survey is to analyze the opportunities, challenges and benefits of using e-textbooks at school. 1005 respondents: 352 students, 296 teachers, 357 parents took part in the research.

15 experts (the representatives of the Department of Education, school leaders, coordinators responsible for informatization of education in schools, IT teachers) were involved in the definition of organizational, psychological and pedagogical conditions for introducing e-textbooks.

The schools that took part in the study included schools, gymnasiums, lyceums and special needs boarding schools. This provided the representativeness of the sample and the completeness and reliability of the reflection of the features of secondary education institutions in the Ukrainian capital. All educational institutions that participated in the experiment held the council meetings and formed supervisory and experimental groups of pupils of the 5 th and 6 th grades. 


\section{Participants}

At the first stage (diagnostic) a survey of teachers of advanced training courses on the use of e-textbooks in professional activities was held. The Center for Scientific and Educational Innovation and Monitoring in Kyiv conducted a survey of the community of teachers and parents on their attitude towards the introduction of e-textbooks instead of printed ones, to the safety of their use for students' health. 215 respondents attended the open online survey: 62 students' parents, 153 teachers (headmasters, teachers).

At the second stage of the experiment, 13 institutions of comprehensive secondary education in Kyiv, in which this technology was introduced during the year, participated in questionnaires and interviews about the possibilities, challenges and advantages of introducing e-textbooks. The number of respondents was 285 people: 53 teachers, 154 pupils of the $6^{\text {th }}$ grade, 78 parents.

At the third stage, 12 institutions of secondary education in the city of Kyiv participated in the survey. They joined the introduction of e-textbooks, taking into account the experience of educational institutions, which have already used e-textbooks for a year. The number of respondents was 505 people, including 90 teachers, 198 students of the $5^{\text {th }}$ grade and 217 parents.

\section{Data Collection and Analysis}

The following tools were used to collect data in this study: questionnaires for students, teachers and parents. Participants were provided with a questionnaire on the Internet, answers were given anonymously, indicating only the name of the school in which the student is studying, or the teacher is working, the analysis of the documents, the analysis of school reports and consultation requests that implement experimental work, the analysis of general information for medical examinations of students.

\section{FINDINGS}

At the first stage of the experiment, we determined the importance of certain conditions that influence the introduction of e-textbooks using the method of determining the relative frequency of the choice of the experts (Smirnov, 1990).

It should be noted that a group rating is considered to be sufficiently reliable only in case of a high level of consensus among the experts. Therefore, the statistical processing of information obtained from the experts also includes an assessment of the level of consensus among the experts, which was determined using Kendall's coefficient of concordance (W).

$$
v=\frac{\sum_{i=1}^{n} x_{i}}{T \cdot n}, \text { where }
$$

$\mathrm{v}$ - relative frequency of the selected indicator;

$\mathrm{n}$ - the number of experts;

T- the highest score according to the applied scale;

- evaluation by an i expert;

$\sum_{i=1}^{n} x_{i}$ - the sum of points according to the chosen indicator.

Scoring: significant-3 points, partly significant (rather yes, than no) - 2 points, partly negatively significant (rather no, than yes) - 1 point, insignificant - 0 . 
Table 1. The importance of conditions that affect the use of e-textbooks in the educational process

\begin{tabular}{|c|c|c|c|c|c|c|}
\hline \multirow[b]{2}{*}{ Conditions (factors) } & \multicolumn{4}{|c|}{ Expert assessments } & \multirow[b]{2}{*}{$\Sigma$} & \multirow[b]{2}{*}{ v } \\
\hline & 0 & 1 & 2 & 3 & & \\
\hline Educational policy in the field of eLearning introduction & 0 & 4 & 5 & 6 & 32 & 0.71 \\
\hline $\begin{array}{l}\text { Availability and variety of e-textbooks and e-books on the market of } \\
\text { educational services }\end{array}$ & 0 & 2 & 8 & 5 & 33 & 0.73 \\
\hline Logistic and methodological support & 0 & 3 & 4 & 8 & 35 & 0.77 \\
\hline Ergonomics & 0 & 4 & 8 & 3 & 29 & 0.64 \\
\hline $\begin{array}{l}\text { The readiness of teachers, students, their parents to use e-textbooks and } \\
\text { e-books }\end{array}$ & 0 & 7 & 4 & 4 & 27 & 0.60 \\
\hline
\end{tabular}

All the experts noted the importance of the proposed conditions for the effective use of e-textbooks in the educational process. The functional capabilities of e-textbooks, their methodological and methodical components have the greatest influence on the effectiveness of the introduction of these tools in the educational process.

Verification of the consistency of expert assessments is checked by the coefficient of concordation, which is calculated by the formula:

$$
W=\frac{12 \cdot \sum(x-\bar{x})^{2}}{m^{2}\left(n^{3}-n\right)}
$$

$\mathrm{W}=0.528$, indicating an average degree of consistency of expert assessments.

The organizational, psychological and pedagogical conditions for using different types of e-books and e-textbooks at school can be defined as a set of factors that provide the organization, regulation, interaction of objects and phenomena of the pedagogical process to ensure quality education using eLearning tools.

\section{The First Condition: Educational Policy in the Field of e-Learning Introduction}

The e-book market is chaotic. For example, American schools offer a number of business models for the creation of a collection of e-books and e-textbooks: subscription to permanent access, license for a certain period, license with a certain amount of traffic, the simultaneous use with other digital products, the usage fee (for example, price per download). The New York Department of Education is contracting with Amazon to provide access to the e-collection to 1,800 public schools and, accordingly, 1.1 million students. The experience when every school bought e-books on its own was found to be ineffective from a financial point of view. Amazon offers the delivery of e-textbooks and other electronic content to the Education Department and manages it. At the same time, specialized tools allow teachers to track student progress, while students can use the built-in vocabulary and give feedback on the content. A model with constant unlimited access is the most popular among schools: the school pays for one copy of the publication, which can be used indefinitely (Ivashina, 2015).

A similar situation is with the use of e-textbooks and e-books in Ukraine, where since 2000s the educational e-books and e-textbooks market has developed. Untill 2018, teachers and schools themselves identified the need for e-textbooks, according to the proposals (https://novashkola.ua, novashkola.com.ua, kmmedia.com. ua/books/, rozumniki.net) and their own IT infrastructure.

The survey of 300 teachers in advanced training courses showed that most of them (56.5\%) episodically introduce e-textbooks into the educational process, and $23.9 \%$ of teachers do this systematically. 


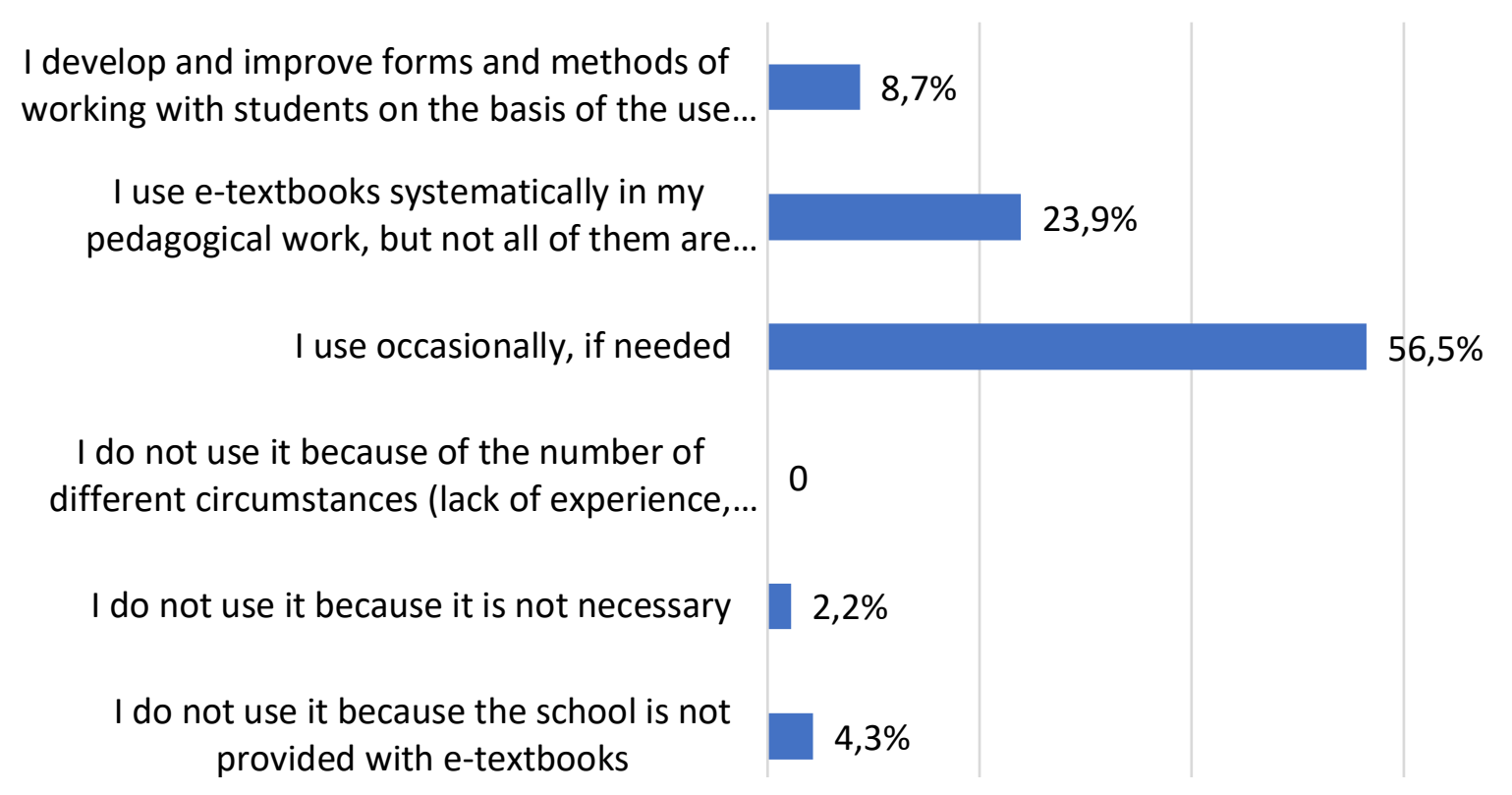

Figure 2. Teachers' responses as for the use of e-textbooks, $\%$

However, the "Experiment on the implementation of the electronic textbook and electronic platform" has begun in Ukraine since 2018. The main purpose of it is to create the preconditions for the development of a system for the production of quality educational electronic content and to provide access to it for applicants of secondary education.

The study of the views of parents and teachers at the first stage of the experiment revealed that, in general, respondents favor the replacement of printed textbooks by electronic ones. More than half of parents (58.1\%) are interested in innovations. The obtained results testify to the mixed opinion of teachers about the transfer of all schools to electronic textbooks. Although the majority (55.2\%) of teachers are more likely to approve such a changeover, their opinion is uncertain, because the number of the teachers who fully endorse such a decision is $0 \%$. More than a third of teachers and educators (36\%) do not approve the idea of switching to e-textbooks. For $73.2 \%$ of respondents, it's important to use e-textbooks free of charge and to propose government funding for innovation. Only $25.2 \%$ of respondents indicated readiness to refund the money for an e-textbook in the case if it was damaged. Parents and teachers have emphasized the need for educational policy on the introduction of e-textbooks and e-books.

Educational policy (at state, regional, educational institution level) in the field of introduction of eLearning (requirements for compulsory e-textbooks, financial support for the purchase of e-textbooks, examination, standards for e-textbooks, etc.) promote the systemic and efficient use of e-books and e-textbooks at school.

\section{The Second Condition: Availability and Variety of e-Textbooks and e-Books on the Market of Educational Services}

Let's consider what characteristics of e-textbooks and e-books affect their choice at school. 


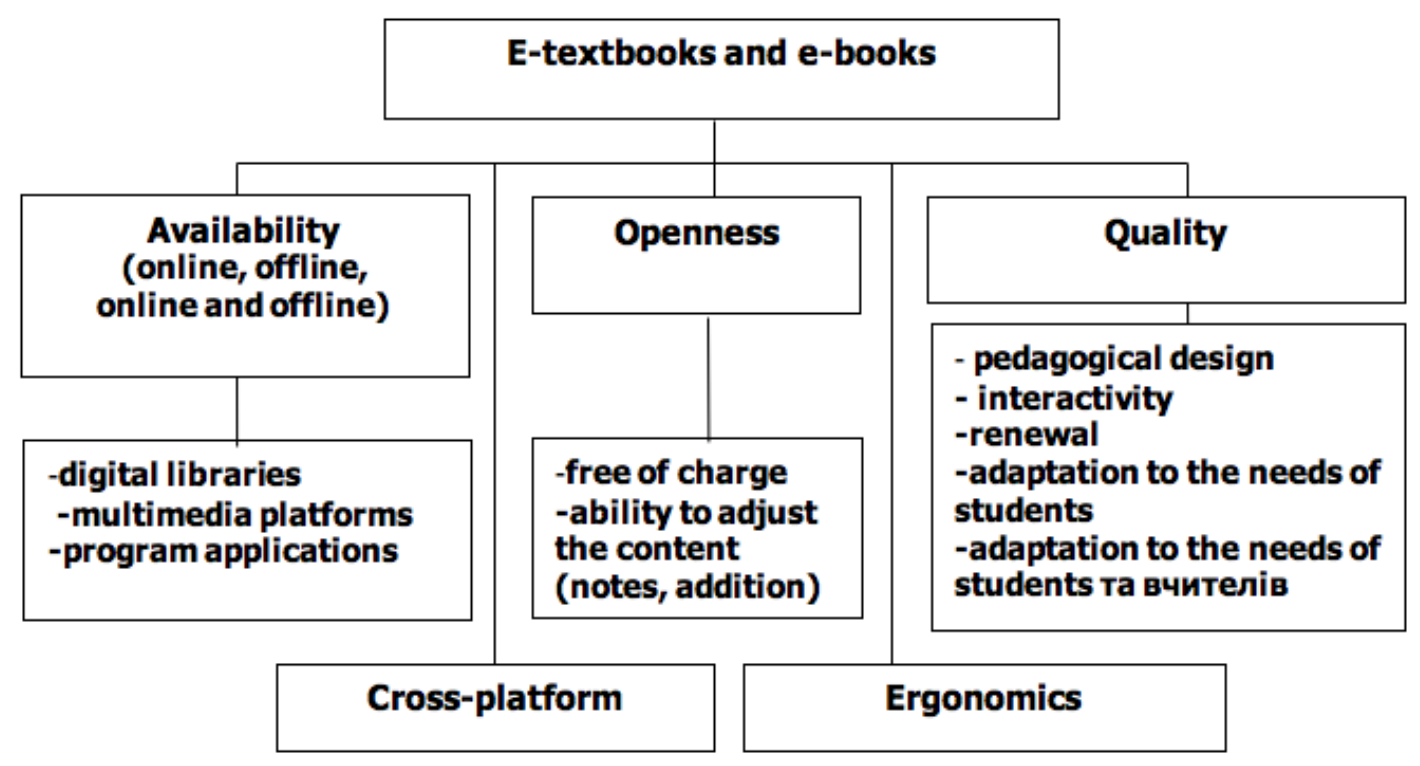

Figure 3. Characteristics of e-textbooks and e-books that affect their choice for the use at school

The variety of e-textbooks on the educational market, globalization, the development of ICTs enables teachers to choose any textbooks and use open educational electronic resources (digital encyclopedias, libraries). Characteristics of e-textbooks are basic to determine their price, the devices on which they will be installed, the need of the access to the Internet, that is logistical support of schools. E-textbooks should be designed to support various operating systems, such as Windows, open source Linux software for PCs and iOS, open source Android software for smart devices, and affordable and open-source, high-quality content.

Table 2. Students' answers to the question: "What e-textbooks are more convenient for you to work with?", \%

\begin{tabular}{lcc}
\multicolumn{1}{c}{ Characteristics of e-textbooks } & $\begin{array}{c}\text { At the second stage of the } \\
\text { experiment, \% }\end{array}$ & $\begin{array}{c}\text { At the third stage of } \\
\text { the experiment, } \%\end{array}$ \\
\hline e-textbooks that contain videos, presentations, and tests & 46.7 & 45.5 \\
\hline equally interesting and convenient & 36.4 & 29.3 \\
\hline those that completely repeat printed textbooks & 16.9 & 16.7 \\
\hline
\end{tabular}

Table 3. According to the teachers the benefits of using e-textbooks are:

\begin{tabular}{ll}
\hline interest of students & $79.2 \%$ \\
\hline the amount of illustrative material that provides a practical visual training & $67.9 \%$ \\
\hline simplifying of work with the content due to tabs and page lookup capabilities & $64.2 \%$ \\
\hline the ability to allocate individual words and phrases for clarity and concentration of attention & $35.8 \%$ \\
\hline
\end{tabular}

Table 4. According to the students the benefits of using e-textbooks are:

\begin{tabular}{lc}
\hline \multicolumn{1}{c}{ The benefits of using e-textbooks } & $\%$ \\
\hline the school bag becomes lighter & 82.5 \\
\hline you can quickly find the right information & 30.5 \\
\hline you can work on different gadgets both at home and at scool & 17.5 \\
\hline modern submission of information & 48.1 \\
\hline I like to use while studying & 50.0 \\
\hline
\end{tabular}

Teachers should provide a learning environment that uses existing technology. Modern technological advances facilitate teachers' access to differentiated material and allow them to create their own textbooks and distribute them on the Internet without involving publishing networks (FlipSnack, Batalugu, Storyjumper, 
Storycove.com, RealeWriter, My e-book, Shasoft e-book, Kindle). The respondents noted that the creation of their own textbooks is an opportunity, but "it depends on the topic." Others claimed that it would be better to have a database of teaching materials, prepared by experts and authors of printed textbooks. You can use amazon.com, www.apple.com/ipad en.wikipedia.org, ck12.org, discoveryeducation.com. Teachers can download e-textbooks from https://play.google.com or create their own (wikibooks.org).

Table 5. Teachers' opinion on the basic conditions for the effective use of e-textbooks at the lessons, \%

\begin{tabular}{ll}
\hline The effective use of e-textbooks at the lessons & $\%$ \\
\hline shock resistance of the device & 66.0 \\
\hline the e-textbook should match the paper counterpart & 62.3 \\
\hline availability of the Internet & 62.3 \\
\hline the battery life of the device & 58.5 \\
\hline free device & 54.7 \\
\hline the ability of a teacher to work with a laptop at home & 43.4 \\
\hline availability of installed programs to create documents, presentations, etc. & 41.5 \\
\hline the ability to set up parental controls on the device (restricting access to specific sites, programs, time settings) & 37.7 \\
\hline possibility of software to update e-textbooks & 35.8 \\
\hline intuitive interface (ease of the use of an e-textbook) & 34,0 \\
\hline using devices in the network to control students' work & 34.0 \\
\hline equipping classes with broader desks & 24.5 \\
\hline two projectors & 15.1 \\
\hline
\end{tabular}

Creating an information and education environment and providing it with e-books and e-textbooks can encourage students to network and collaborate with other members of the learning community. It also develops distance education and self-education. For example, the resource for creating e-books and e-textbooks is the Lightbox multimedia educational platform that allows you to embed videos, audio files, slideshows, Google maps, web links, etc. in the materials for a specific topic. It's a fully interactive, multidimensional, additional solution for students who seek to improve communication skills and literacy (Ivashina, 2015).

\section{The Third Condition: Logistic and Methodological Support}

Availability of IT infrastructure in an educational institution for the introduction of e-textbooks is the following: hardware (netbooks, computers, tablets, e-books), a local network, access to the Internet; licensed software (e-textbooks, e-books); access to digital libraries, the use of cloud services, Web 2.0, etc.; support services (system administrators, consultants, computer science teachers) for updating e-textbooks, installing them on the device, providing data protection and copyright; methodical recommendations for the use of e-books, e-textbooks at school.

After the first stage of the experiment, schools determined the need for the purchase of special cabinets for storing computer equipment and ensuring their work in sanitary norms. New features of devices (RAM and hard disk, batteries, etc.) are determined. There was a problem with installing additional software with antivirus and parental control programs.

The teachers found the need for methodological recommendations for delivering lessons with e-textbooks, the preparation of lessons using lesson designers and proposed the creation of a database of teaching materials for the experience exchange.

Teachers' own methodological materials, which they can control and assume responsibility for the structure, updating and implementation of the educational process helped the teachers to acquire both the experience of self-replenishment, renewal of professional knowledge, personal involvement in this process, responsibility for it, and opportunities to manage their resources, to offer them for studying. 
Ensuring the monitoring and control over the use of e-textbooks by teachers and students contributed to the comprehensive control of the learning process, the objectivity of evaluation. Teachers needed an analysis of the statistical information accumulated during the learning process, such as the number of requests for help, the time spent on individual tasks, the problems with downloading e-textbooks, etc.

\section{The Fourth Condition: Ergonomics}

Concerns about the negative impact on the health of children were reported by only $12.4 \%$ of respondents, $17.1 \%$ were unable to determine the answer, and $70.5 \%$ are sure that there is not such a threat. According to the respondents, the main requirement for electronic textbooks is safety for the user's eyesight. The respondents identified the main criteria of e-textbooks: high-quality image $(76.7 \%)$, ease of use $(73.6 \%)$, the ability to update the content $(63.6 \%)$. Among parents who agreed on the necessity to use e-textbooks, the majority were in favor of introducing them to 10-year-old students (35.5\%). 22.6\% of the respondents agreed that e-textbooks can be introduced from the age of 6 , and only $14.5 \%$ - from the age of 16 , others believe that any age is acceptable. After the introduction of e-textbooks in experimental groups, the opinion of parents almost did not change: $36.4 \%$ of them indicated that the most expedient to study using e-books and e-textbooks from the 5 th grade.

Table 6. Parents' answers to the question: "In your opinion, when is the most expedient to switch to electronic textbooks at school?”, \%

\begin{tabular}{lr}
\hline Grade & $\%$ \\
\hline from the $1^{\text {st }}$ grade & 6.9 \\
\hline in elementary school, excluding the $1^{\text {st }}$ grade & 11.5 \\
\hline from the $5^{\text {th }}$ grade & 36.4 \\
\hline in secondary school, but not in the $5^{\text {th }}$ grade & 13.4 \\
\hline in high school (from the $10^{\text {th }}$ grade) & 11.5 \\
\hline hard to say & 15.7 \\
\hline no matter what grade & 4.6 \\
\hline
\end{tabular}

Regardless of the stage at which e-books are implemented, interviewed institutions are (http://archive. chytomo.com/news/e-pidruchniki-v-shkolax-amerikanskij-dosvid), all of them insist that the combination of printed and electronic content is a valid standard in schools and school libraries, besides, this tendency will be maintained for a long time.

In our survey, almost half of the students like to work with both printed and electronic textbooks.

Table 7. The students' choice for the use of printed and electronic textbooks, $\%$

\begin{tabular}{ccc}
\hline The students' choice & $\begin{array}{c}\text { At the second stage of the experiment, } \\
\%\end{array}$ & $\begin{array}{c}\text { At the third stage of the experiment, } \\
\%\end{array}$ \\
\hline printed and electronic & 46.5 & 48.1 \\
\hline electronic & 38.9 & 42.2 \\
\hline printed & 14.6 & 9.7 \\
\hline
\end{tabular}

Table 8. The respondents' answers to the question: "How often should e-textbooks be used in the educational process?”, \%

\begin{tabular}{lccc}
\hline \multicolumn{1}{c}{ The respondents' answers } & parents, $\%$ & teachers, $\%$ & students, $\%$ \\
\hline from time to time, along with printed & 42.3 & 52.8 & 33.1 \\
\hline sometimes, e-textbooks are auxiliary & 30.9 & 32.1 & 22.7 \\
\hline constantly & 24.2 & 13.2 & 29.2 \\
\hline difficult to answer & 2.6 & 1.9 & 12.1 \\
\hline should not be used & 0.0 & 0.0 & 1.9 \\
\hline
\end{tabular}


Regardless of whether the book is published as a textbook, a reference to a source, or a different type, most readers report using e-books as directories. They look for specific information and read short sections of the required information in all types of books (Nicholas et al., 2007).

Table 9. The respondents' answers to the question: "Do you know why your child prefers to use a computer or other gadgets? ", \%

\begin{tabular}{lcccc}
\hline \multirow{2}{*}{\begin{tabular}{l} 
The respondents' answers \\
\cline { 2 - 5 }
\end{tabular}} & $\begin{array}{c}\text { parents } \\
\text { at the second stage of } \\
\text { the experiment, } \%\end{array}$ & $\begin{array}{c}\text { at the third stage of the } \\
\text { experiment, } \%\end{array}$ \\
\hline search for educational material, doing homework & 73.1 & 63.6 & 73.3 & 79.3 \\
\hline games & 60.3 & 44.2 & 65.0 & 62.6 \\
\hline entertainment (music, video) & 60.3 & 60.2 & 59.9 & 76.8 \\
\hline training (simulators in Mathematics, educational games) & 50.0 & 50.0 & 42.9 & 47.5 \\
\hline communication (social networks, texting) & 50.0 & 38.3 & 50.7 & 64.1 \\
\hline viewing interesting web pages & 46.2 & 40.3 & 46.5 & 58.1 \\
\hline reading (electronic libraries) & 16.7 & 38.3 & 31.3 & 50.5 \\
\hline creating web pages, groups & 7.7 & 14.3 & 14.3 & 25.3 \\
\hline
\end{tabular}

Answering an open question, parents added that their children used their computers for online blogging, watching workshops on YouTube, watching cartoons and movies. Parents believe that while learning through e-textbooks, the children began to spend more time on a computer (or other gadget) $(32.3 \%)$. This opinion was not confirmed by $42.4 \%$ of parents and $25.3 \%$ of respondents could not confidently say about the time spent by the child on gadgets.

Table 10. Parents' answers to the question: "Did you notice the following problems?", \%

\begin{tabular}{lcc}
\hline \multicolumn{1}{c}{ Parents' answers } & $\%$ & $\%$ \\
\hline problems in communicating with classmates, family members, friends & 14.7 & 17.9 \\
\hline staying at a computer for more time than talking to you & 49.8 & 34.6 \\
\hline worsening mood when there is no access to the computer & 43.8 & 39.7 \\
\hline sitting at a computer at night & 9.2 & 9.0 \\
\hline eating in front of the computer & 31.3 & 32.1 \\
\hline conflicts with parents because of a computer & 31.3 & 26.9 \\
\hline
\end{tabular}

Sixth grade students use computers (or other gadgets) to find educational material, do homework $(73.1 \%$ of parents, $63.6 \%$ of students), games (60.3\% and $44.2 \%$ respectively), entertainment (music, video) $59.0 \%$ and $55.2 \%$ respectively), training (math's, educational games, etc.) $(50.0 \%$ and $50.0 \%$ respectively) and communication (social networks, texting) $(50.0 \%$ and $38.3 \%$ respectively).

\section{The Fifth Condition: The Readiness of Teachers, Students, Their Parents to Use e-Textbooks and e-Books}

This condition characterizes the positive motivation of teachers and students to study and use e-textbooks for personal and professional growth. The use of digital means contributes to the self-education of teachers, the reorientation of teachers from the transfer of ready-made knowledge to students to the role of a consultant, a leader who indirectly organizes and encourages participants in learning activities, provides more opportunities for self-actualization and development of students. The digital competence of teachers, students and even their parents also needs special attention. Both teachers and students noted that the introduction of e-textbooks and e-books contributed to the development of their ICT competencies. 


\section{DISCUSSIONS AND CONCLUSION}

The use of digital spaces should help develop not only the knowledge and skills of a child, but also the skills and competences for working with information and its use on the basis of critical thinking, problem-solving skills, creativity and innovation, be capable of cooperation and leadership, intercultural understanding, communication. This contributes to changing approaches to textbooks and resources used in education.

Modern education requires a textbook of a new format that differs from the traditional format in the form of a book. The studies have shown that the new textbook should form the educational environment. Textbooks of the new generation have the following characteristics: displaying results, ensuring maximum independence of students in the study, taking into account the needs and characteristics of students, providing opportunities for students to create their own educational product. Such an environment (Ivanova \& Osmolovskaya, 2016) is capable of creating constructive tasks and developing skills of the 21 st century.

Survey and observation of the work of experimental schools with e-textbooks showed their demanded functions and possibilities. They are available (both online and offline) to organize distance and mixed methods of learning. E-textbooks are also free of charge, open, adaptable, qualitative (interactivity, multimedia, pedagogical design, compliance with state standards), cross-platform, ergonomic.

The research (Wright, Fugett \& Caputa, 2013) shows the similarities and differences in the productivity of reading and understanding in digital formats compared to printed forms. The authors compared the understanding of words from two sources of reading (electronic and printed books) and argued that the understanding of written materials remains unchanged for students, regardless of the presentation method (printed and digital).

B. Knight, notes that in the future, an e-textbook will be self-sufficient, open to access by a constantly changing book, developed by everyone without belonging to anyone (Knight, 2015). The authors of the study determined that particular attention should be given to understanding, preserving information and feedback when working with e-textbooks. They insist on the need to use electronic tools such as notes, annotations, tags, hypertexts and backlighting (Embong et al., 2012). It is more convenient for students to work with e-textbooks, which have interactive elements and compulsory elements are videos, presentations, and tests. The development of ICT promotes the creation of multimedia platforms that enable teachers to create their own eLearning resources and use all possibilities of open educational electronic systems.

It is necessary to build a new generation of electronic textbooks, including content, semantic enhancement and a case study. The informational model of electronic textbooks should include a knowledge base and ontology of the course, the use of cloud technologies, multimedia, Learning Record Store for studying and analyzing the outcomes of teaching, tracking behavioral data of students and using them (Zhang, \& Zhang, 2015).

A general guideline for the successful use of e-textbooks is presenting best practices, teacher training, school administrators of the technology of using e-books and e-textbooks; selection of software and hardware and provision of educational institutions; consultations, methodological recommendations for participants in the educational process that do not have the necessary digital competence or have special needs; helping parents adapt to using their children's e-books and e-textbooks at home; updating e-books and e-textbooks and advising on working with devices that have e-Apps (Embong et al., 2012).

The definition of organizational, psychological and pedagogical conditions for the introduction of e-textbooks was facilitated by the opinion of 15 experts who were involved in the assessment of factors, criteria and indicators of effective use of ICT at school.

The experts identified 4 basic conditions for the introduction of e-textbooks and e-books at school.

- Educational policy (state, regional, educational level) on the introduction of eLearning, e-textbooks (requirements for compulsory e-textbooks, financial support for the purchase of e-textbooks, examination, standards for e-textbooks, etc.).

- The availability and diversity of e-textbooks and e-books on the educational services market. Logistic and methodological support. The availability of IT infrastructure in an educational institution for the introduction of e-textbooks: hardware (netbooks, computers, tablets, e-books), the Internet access, the availability of local area network; software (access to digital libraries, the use of cloud services, Web 2.0, etc.); support services (system administrators, consultants, computer science teachers) for updating e-textbooks, installing them on the device, providing data protection and copyright; educational and methodological support (e-books, e-textbooks, educational-methodical complexes, methodical recommendations on the use of hardware and software, e-resources of best practices). 
- Ergonomics (sanitary norms of using e-textbooks to protect students from the negative effects of devices on their health).

- Readiness of teachers, students, their parents to use e-textbooks and e-books (digital competence of teachers and students).

Students, teachers and parents have confirmed their readiness to use e-textbooks and e-books under the conditions of material and technical provision of educational institutions, observance of sanitary norms, development of their own digital competence.

The research shows the prospects of using e-books and e-textbooks at school and needs further implementation. The conducted research does not exhaust all aspects of the mentioned scientific problem and needs further development of the diagnostics of the quality of education to substantiate the methods of using different types of e-textbooks and e-books taking into account the age of students based on the views of the authors of textbooks, teachers, students and their parents.

A promising area for the research is an analysis of the development of students' logical, abstract, spatial, critical thinking while using electronic textbooks and e-books and a summary of the results on the formation of digital competence and information culture of participants in the educational process.

Acknowledgements: We would like to express our gratitude to Kyiv Center for Scientific and Educational Innovations and Monitoring for conducting the survey.

\section{BIODATA and CONTACT ADDRESSES of AUTHOR}

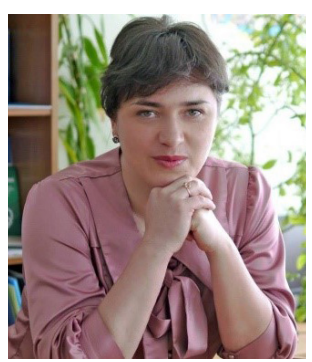

Dr. Iryna VOROTNYKOVA, PhD in Pedagogic Sciences, Associate Professor of the Department of Natural Sciences and Mathematics Education and Technologies at the Institute of In-Service Teachers' Training of Borys Grinchenko Kyiv University. Work experience in the sphere of secondary education is 6 years, in postgraduate pedagogical education - 15 years. Previous positions: a teacher of Information Science, methodologist, lecturer, Deputy Director of the Center of Distance Education, Deputy Director of the Department of Information Technology. Current position: a coordinator of projects, an author of works on the implementation of ICT in education, distance education.

\section{Iryna VOROTNYKOVA}

Address: Department of Natural Sciences and Mathematics Education and Technologies

Borys Grinchenko Kyiv University, Kyiv, Ave. P. Tychyny 22a, 02152, Ukraine

Phone: +38 0502851789

E-mail: irvorotnikova@gmail.com, i.vorotnykova@kubg.edu.ua

\section{REFERENCES}

Anameric, H., \& Rukanc1, F. (2003). E-kitap teknolojisi ve kullanımı. Turk Kutuphaneciligi,17(2), 147-166.

Armstrong, C. (2008). Books in a virtual world: The evolution of the e-book and its lexicon.Journal of Librarianship and Information Science,40(3), 193-206.

Batoon, P., Victoria, M., Glasserman Morales, L. D., \& Yanez Figueroa, J. A. (2018). Instructional Design to Measure the Efficacy of Interactive E-Books in a High School Setting. Turkish Online Journal of Distance Education, 19(2), 47-60.

Brueck, J. S., \& Lenhart, L. A. (2015). E-Books and TPACK. The Reading Teacher,68(5), 373-376.

Choi, P. M. S., \& Lam, S. S. (2018). A hierarchical model for developing e-textbook to transform teaching and learning.Interactive Technology and Smart Education, 15(2), 92-103

Embong, A., Noor, A. M., Hashim, H. M., Ali, R. M., \& Shaari, Z. H. (2012). E-Books as textbooks in the classroom. Cyprus International Conference on Educational Research (Cy-Icer-2012), 47, (pp. 18021809). doi:10.1016/j.sbspro.2012.06.903.

Fojtik, R. (2015). Ebooks and mobile devices in education. 4th World Conference on Educational Technology Researches (Wcetr-2014), 182, (pp.742-745). doi:10.1016/j.sbspro.2015.04.824. 
Ghaem Sigarchian, H., Logghe, S., Verborgh, R., De Neve, W., Salliau, F., Mannens, E., ... \& Schuurman, D. (2018). Hybrid e-TextBooks as comprehensive interactive learning environments.Interactive Learning Environments,26(4), 486-505.

Goodyear, P., \& Retalis, S. (2010). Technology-enhanced learning.Rotterdam: Sense Publishers.

Grammenos, D., Savidis, A., Georgalis, Y., Bourdenas, T., Stephanidis, C., \& Acm. (2007a). Dual Educational Electronic Textbooks: The Starlight Platform. Assets'07: Proceedings of the Ninth International Acm Sigaccess Conference on Computers and Accessibility, (pp. 107-114).

Gronlund, Å., Wiklund, M., \& Boo, R. (2018). No name, no game: Challenges to use of collaborative digital textbooks.Education and Information Technologies,23(3), 1359-1375.

Illowsky, B. S., Hilton, J., Whiting, J., \& Ackerman, J. D. (2016). Examining Student Perception of an Open Statistics Book. Open Praxis, 8(3), 265-276. doi:10.5944/openpraxis.8.3.304.

Ivanova, E. O., \& Osmolovskaya, I. M. (2016, Jun 06-07). Electronic textbooks: didactic aspect. Paper presented at the International Conference on Education Environment for the Information Age (EEIA), RUSSIA. Moscow.

Ivashina A. (October, 2015). E-textbooks in schools: American experience. Retrieved June 28, 2018 from http:// archive.chytomo.com/news/e-pidruchniki-v-shkolax-amerikanskij-dosvid

Jang, S. (2014). Study on service models of digital textbooks in cloud computing environment for SMART education. International Journal of u-and e-Service, Science and Technology,7(1), 73-82.

Keats, D., \& Schmidt, J. P. (2007). The genesis and emergence of Education 3.0 in higher education and its potential for Africa. First Monday, 12(3).

Knight, B. A. (2015). Teachers' use of textbooks in the digital age.Cogent education,2(1), 1015812.

Koehler, M. J., Mishra, P., \& Cain, W. (2015). What Is Technological Pedagogical Content Knowledge (TPACK)? Virtualidad Educacion Y Ciencia, 6(10), 9-23.

Lee, H. J., Messom, C., \& Kok-Lim, A. Y. (2013). Can an electronic textbooks be part of K-12 education?: Challenges, technological solutions and open issues. TOJET: The Turkish Online Journal of Educational Technology, 12(1).

Lokar, M. (2015). The future of e-textbooks.Int. J. Technol. Math. Educ,22(3), 101-106.

Maynard, S., \& Cheyne, E. (2005b). Can electronic textbooks help children to learn? Electronic Library, 23(1), 103-115. doi:10.1108/02640470510582781.

McFadden, C. (2012). Are textbooks dead? Making sense of the digital transition.Publishing Research Quarterly,28(2), 93-99.

Millar, M., \& Schrier, T. (2015). Digital or printed textbooks: which do students prefer and why?.Journal of Teaching in Travel \& Tourism,15(2), 166-185.

Morgan, E.L. (1999) Electronic Books and Related Technologies. Computers in Libraries, 19, 36-39.

Nicholas, D., Rowlands, I., Clark, D., Huntington, P., Jamali, H. R., \& Olle, C. (2008). UK scholarly e-book usage: a landmark survey. Aslib Proceedings, 60(4), 311-334. doi:10.1108/00012530810887962.

Pesek, I., Zmazek, B., \& Mohorcic, G. (2014). From e-materials to i-textbooks. W: I. Pesek, B. Zmazek i V. Mileksic (red.). Slovenian i-textbooks. Ljubljana.

Prawiradilaga, D. S. (2016). Mozaik Teknologi Pendidikan: E-Learning. Kencana.

Rowlands, I., Nicholas, D., Jamali, H. R., \& Huntington, P. (2007). What do faculty and students really think about e-books? Aslib Proceedings, 59(6), 489-511. doi:10.1108/00012530710839588.

Smirnov, A.V. (1990). Statistical processing of questionnaires containing ball scales. The reserves of the intensification of the pedagogical educational process: Interun. Sat scientific work, 117-121.

Swidan, O., \& Abu-Abdoon, H. (2018). Educating teachers to use e-textbooks as a means to prompt argumentation and creative reasoning.Edited by: Hans-Georg Weigand, Alison Clark-Wilson, Ana Doneuska, 265.

Wright, S., Fugett, A., \& Caputa, F. (2013). Using E-readers and Internet Resources to Support Comprehension. Educational Technology \& Society, 16(1), 367-379.

Zhang, J., \& Zhang, L. (2015). Semantic Enhanced e-Textbooks: Information Model and Its Application. Computer Science,2(6), 213-222. 